\title{
THE INFLUENCE OF NATURAL FERMENTATION OF RAW MILK AND THE STARTER CULTURES USED IN THE YOGURT AND IN THE SOUR CREAM PRODUCTION ON THE DENITRIFICATION
}

\author{
S. Pyskiv, M. Kukhtyn \\ Ternopil Ivan Puluj National Technical University
}

\begin{tabular}{|c|c|}
\hline Key words: & ABSTRACT \\
\hline $\begin{array}{l}\text { milk, } \\
\text { yogurt, } \\
\text { sour cream, } \\
\text { denitrification, } \\
\text { starter, } \\
\text { fermentation }\end{array}$ & $\begin{array}{l}\text { It is known that for the manufacture of the high-quality } \\
\text { dairy products, especially for the infant food, it is necessary to } \\
\text { use milk, the content of nitrates in which should be lower than } \\
5 \mathrm{mg} / \mathrm{kg} \text {. However, in the certain periods of the year, cow's } \\
\text { milk contains an excessive amount of nitrates. Milk-raw mate- } \\
\text { rial with excessive nitrate content is not suitable for proces- }\end{array}$ \\
\hline $\begin{array}{l}\quad \text { Article history: } \\
\text { Received 15.04.2019 } \\
\text { Received in revised form } \\
16.10 .2019 \\
\text { Accepted } 22.11 .2019\end{array}$ & $\begin{array}{l}\text { sing, which causes the significant raw material and financial } \\
\text { losses. } \\
\text { The objective of this work is to study the peculiarities of } \\
\text { the denitrification process during the natural milk fermen- } \\
\text { tation and in the technology of the cultured dairy products }\end{array}$ \\
\hline $\begin{array}{l}\text { Corresponding author: } \\
\text { prudence.luck@gmail.com }\end{array}$ & $\begin{array}{l}\text { (yogurt and sour cream) with the different nitrate content. } \\
\text { According to the results of the study it was established that } \\
\text { the process of denitrification in milk of natural fermentation is } \\
\text { best done in the first } 24 \text { hours, due to the presence of denit- } \\
\text { rifying bacteria in the raw milk (decreases by about } 3,1 \text { times). } \\
\text { However, the reduction of nitrates to the norms of the } \\
\text { European standard ( } 5 \mathrm{mg} / \mathrm{kg} \text { ) occurs in milk with a content of } \\
\text { nitrates up to } 20-25 \mathrm{mg} / \mathrm{kg} \text {. When the content of nitrates was } \\
30 \mathrm{mg} / \mathrm{kg} \text {, this indicator was not reached. } \\
\text { Obviously, along with a nitrate content in milk of more } \\
\text { than } 20 \mathrm{mg} / \mathrm{kg} \text {, the inhibitory effect of nitrates on the ability of } \\
\text { the microflora of raw milk to denitrification occurs. } \\
\text { It was established that in the production of yogurt the } \\
\text { starter with the content of bacteria Lactobacillus delbrueckii } \\
\text { subsp. bulgaricus and Streptococcus salivarius subsp. Thermo- } \\
\text { philus is used and in the production of sour cream the starter } \\
\text { of mesophilic lactic acid bacteria Lactococcuslactis subsp. } \\
\text { lactis, Lactococcuslactis subsp. diacetylactis, Lactococcusla- } \\
\text { ctis subsp. cremoris is used and the denitrification process does } \\
\text { not occur. The expediency of creating of starter with the con- } \\
\text { tent of the lactic acid microorganisms, which showed the } \\
\text { denitrification ability in the production of sour-milk products, } \\
\text { was substantiated. }\end{array}$ \\
\hline
\end{tabular}

DOI: 10.24263/2225-2916-2019-26-7

(C) С. І. Писків, М. Д. Кухтин, 2019 


\title{
ВПЛИВ ПРИРОДНОГО СКВАШУВАННЯ СИРОГО МОЛОКА ТА ЗАКВАСОЧНИХ КУЛЬТУР ПРИ ВИГОТОВЛЕННІ ЙОГУРТУ І СМЕТАНИ НА ПРОЦЕС ДЕНІТРИФІКАЦІЇ
}

\author{
С. І. Писків, аспірант \\ М. Д. Кухтин, д-р вет. наук \\ Тернопільський національний технічний університет імені І. Пулюя
}

У статmі на основі літературних джерел висвітлено проблему наднормативного вмісту нітратів у молоці-сировині, яке поступає на переробку. Визначено динаміку вмісту нітратів під час самосквашування молока сирого, а також після внесення класичних заквасок у попередньо підготовлене молоко та вершки згідно з технологією виготовлення йогурту і сметани відповідно. У технологічному процесі виробництва йогурту з використанням закваски з вмістом бактерій Lactobacillus delbrueckii subsp. bulgaricus i Streptococcus salivarius subsp. thermophilus ma в технології виробництва сметани на заквасці мезофрільних молочнокислих бактерій Lactococcus lactis subsp. lactis, Lactococcus lactis subsp. diacetylactis, Lactococcus lactis subsp. cremoris визначено, що процес денітрифікації не відбувається. Доведено необхідність пошуку закваски із вмістом молочнокислих мікроорганізмів, яка б проявляла денітрифрікуючу здатність при виготовленні кисломолочних продуктів, зокрема йогурту і сметани.

Ключові слова: молоко, йогурт, сметана, денітрифікація, закваска, сквашування.

Постановка проблеми. Загальновідомо, що нітрати і нітрити у наднормативній кількості в продуктах мають токсичний вплив на організм людини, особливо немовлят [1-3]. Так, у [4-7] зазначається, що в окремі періоди року вміст нітратів у молоці перевищує допустимий норматив (понад 5 мг/кг за європейськими вимогами Г81 і понад 10 мг/кг за українським ДСТУ 3662). В організм великої рогатої худоби (BPX) нітрати можуть потрапити як з кормами, так і 3 водою. Відомо, що у передшлунках корів процес розщеплення нітратів відбувається інтенсивно [9] і через молоко вони виводяться з тваринного організму [10]. Відповідно, коли внутрішня мікрофлора шлунка ВРХ не справляється розщепити ці токсичні речовини, то їхня кількість у молоці може значно перевищувати норму. Як наслідок, молоко-сировина 3 наднормативним вмістом нітратів стає непридатним для використання, а це спричиняє значні сировинні і фінансові втрати. Тож актуальності набуває питання подальшого використання такого молока.

Власна мікрофлора молока-сировини є різноманітною, вона містить молочнокислі бактерії, які відіграють основну роль у процесі самосквашування молока. Дослідження впливу цього процесу на зміну кількості нітратів у молоці з наднормативним вмістом цих токсичних речовин покаже, чи власна мікрофлора молока-сировини проявляє денітрифікуючу здатність. Великий попит серед споживачів має кисломолочна продукція.

У пропонованому дослідженні зосереджена увага на йогурті і сметані класичного способу виробництва. Згідно з ДСТУ 4343 для виготовлення йогурту використовують закваску на основі Lactobacillus delbrueckii subsp. bulgaricus та Streptococcus salivarius subsp thermophilus, яку вносять у попередньо підготовлене молоко. Технологічний процес виробництва сметани ДСТУ 4418 передба- 
чає внесення закваски молочнокислих бактерій у попередньо підготовлені вершки (досліджувалась закваска на основі Lactococcus lactis subsp. lactis, Lactococcus lactis subsp. diacetylactis, Lactococcus lactis subsp. cremoris). Проте, якщо у вихідній сировині є наднормативна кількість нітратів, необхідно з'ясувати, які ж стартові культури проявляють здатність до денітрифікації. Це дасть змогу визначити, чи готова продукція буде безпечною для вживання. На основі отриманих даних буде зроблено висновок стосовно необхідності пошуку шляхів вирішення цієї проблеми.

Мета дослідження: виявлення денітрифікуючої здатності власної мікрофлори сирого молока з наднормативним вмістом нітратів і заквасочних культур (L. d. bulgaricus та S. Thermophiles; L. lactis, L. cremoris, S. diacetylactis), що використовуються у традиційній технології виготовлення кисломолочних продуктів (йогурт і сметана).

Матеріали і методи. Дослідження проводились у науково-дослідній лабораторії кафедри харчової біотехнології і хімії ТНТУ імені Івана Пулюя.

Для експерименту у досліджені проби молока і вершків штучно вносили попередньо підготовлені розчини $\mathrm{KNO}_{3}$, щоб досягти концентрації нітратів у дослідних зразках 10, 20 і 30 мг/кг (така концентрація обрана з урахуванням наших власних досліджень і згідно з даними літературних джерел [6;11]).

Природне сквашування молока проводили за температури $30^{\circ} \mathrm{C}$ упродовж 72 год, а кількість нітратів визначали через 6-12, 24-48, 48-72 год. Внесення закваски для йогурту відбувалося за температури $40-42^{\circ} \mathrm{C}$, що є оптимальним для росту термофільних молочнокислих бактерій. Внесення закваски для сметани проводили при температурі $27 \pm 1^{\circ} \mathrm{C}$, що $є$ оптимальним для росту мезофільних молочнокислих бактерій.

Визначення вмісту нітратів проводили колориметричним методом із застосуванням кадмієвої колонки з подальшим фотометричним визначенням азосполук, що утворюються при взаємодії нітритів з ароматичними амінами (згідно 3 ГОСТ 32257-2013. Молоко и молочная продукция. Метод определения нитратов и нитритов).

Результати досліджень. На першому етапі наукового дослідження вивчався вплив природного сквашування молока-сировини з різним вмістом нітратів на динаміку денітрифікуючого процесу. Зміна вмісту нітратів під час природного сквашування молока наведена на рис. 1.

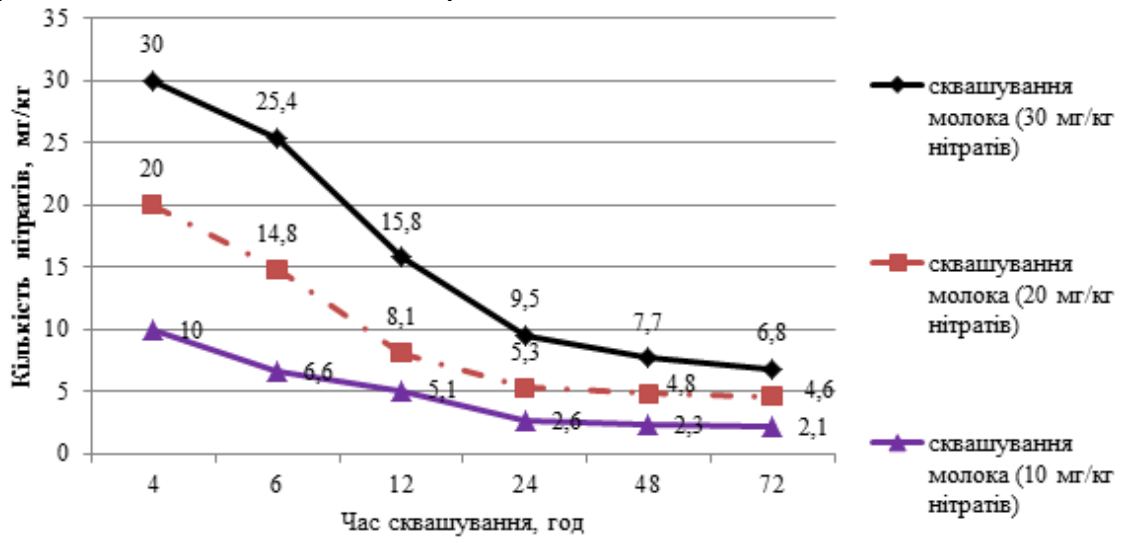

Рис. 1. Динаміка денітрифікуючого процесу під час природного сквашування молока сирого 3 початковим вмістом нітратів 30, 20 і 10 мг/кг 
Як видно 3 рис. 1, спостерігається зменшення кількості нітратів у процесі сквашування молока (з початковим вмістом цих токсичних речовин 30 мг/кг) за температури $30^{\circ} \mathrm{C}$ через 12 год в середньому у 1,9 раза $(\mathrm{P}<0,05)$. Через 24 год вміст нітратів становив 9,5 мг/кг, тобто відбулося зменшення їхнього показника приблизно у 3,1 раза $(\mathrm{P}<0,05)$. Упродовж наступних двох діб відбулося зменшення вмісту нітратів тільки в $1,1-1,2$ раза.

При такому ж сквашуванні молока 3 вмістом нітратів 20 мг/кг через 12 год уміст нітратів у ньому знизився приблизно у 2,5 раза $(\mathrm{P}<0,05)$. Через 24 год вміст нітратів становив 5,3 мг/кг (зменшення у 3,8 раза $(\mathrm{P}<0,05))$. Упродовж наступних двох діб відбулося зниження вмісту нітратів тільки в $1-1,1$ раза.

У третьому зразку молока 3 вмістом нітратів 10 мг/кг під час природного сквашування спостерігалась така динаміка зниження показника нітратів: через 12 год - у 2 рази, через 24 год - у 3,8 раза $(\mathrm{P}<0,05)$. Упродовж наступних двох діб відбулося зменшення вмісту нітратів в $1-1,1$ раза.

Отже, відповідно до результатів дослідження встановлено, що процес денітрифікації у молоці природного сквашування найкраще відбувається в перші 24 год, що пов'язано з наявністю у молоці-сировині денітрифікуючих видів бактерій. Проте зменшення нітратів до норм європейського стандарту (5 мг/кг) відбувається в молоці із вмістом нітратів до 20 мг/кг. При вмісті нітратів більше 20 мг/кг цей показник не було досягнуто, очевидно, високий вміст нітратів гальмує здатність мікрофлори молока-сировини до денітрифікації.

На рис. 2 наведено результати досліджень зміни кількості нітратів під час виготовлення кисломолочного продукту (йогурту) з використанням закваски термофільних бактерій (L. d. bulgaricus та S. thermophilus). Виготовлення йогурту проводилось згідно з технологічними інструкціями резервуарним способом.

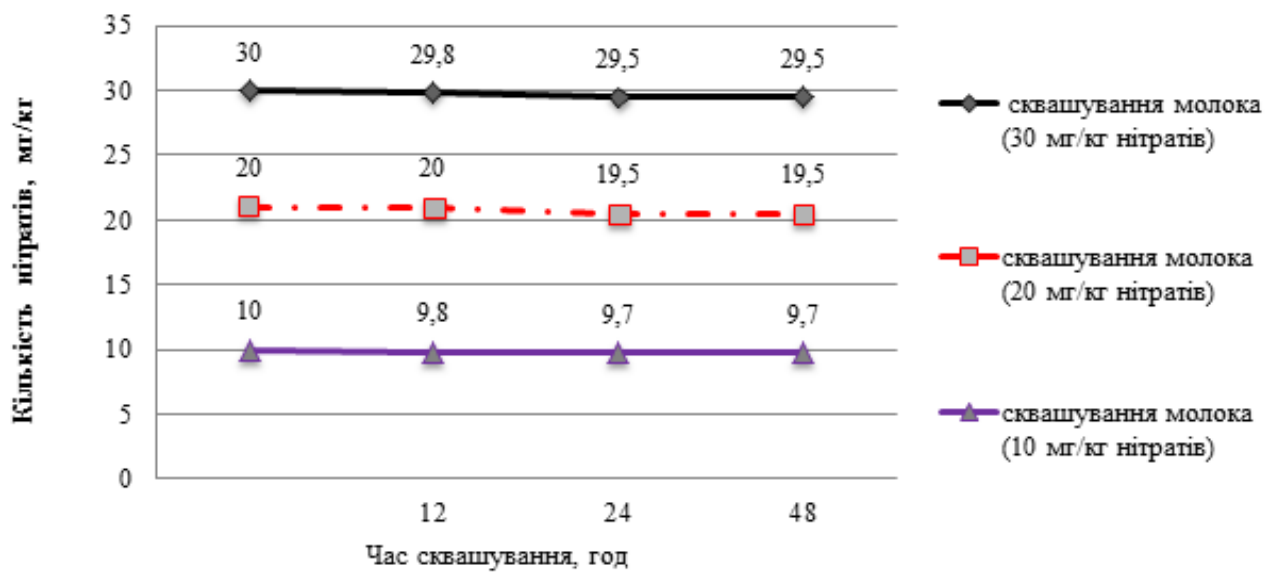

Рис. 2. Динаміка денітрифікуючого процесу при внесенні закваски бактерій L.d. bulgaricus та S. thermophiles для сквашування молока 3 початковим вмістом нітратів 30, 20, 10 мг/кГ

Одержані результати, наведені на рис. 2, вказують, що під час сквашування молока протягом $12-24$ год відбулося невірогідне зменшення вмісту нітратів у кінцевому продукті (на 1,6, 2,3 і 3\% з початковим вмістом нітратів 30, 20 і 10 мг/кг вмістом нітратів відповідно). 
При подальшому сквашуванні через 48 год денітрифікація не відбулась взагалі. Це, очевидно, пов’язано з тим, що молочнокислі бактерії закваски не проявляють денітрифікуючі властивості. Також виявлено, що пастеризація молока не вплинула на зменшення кількості нітратів.

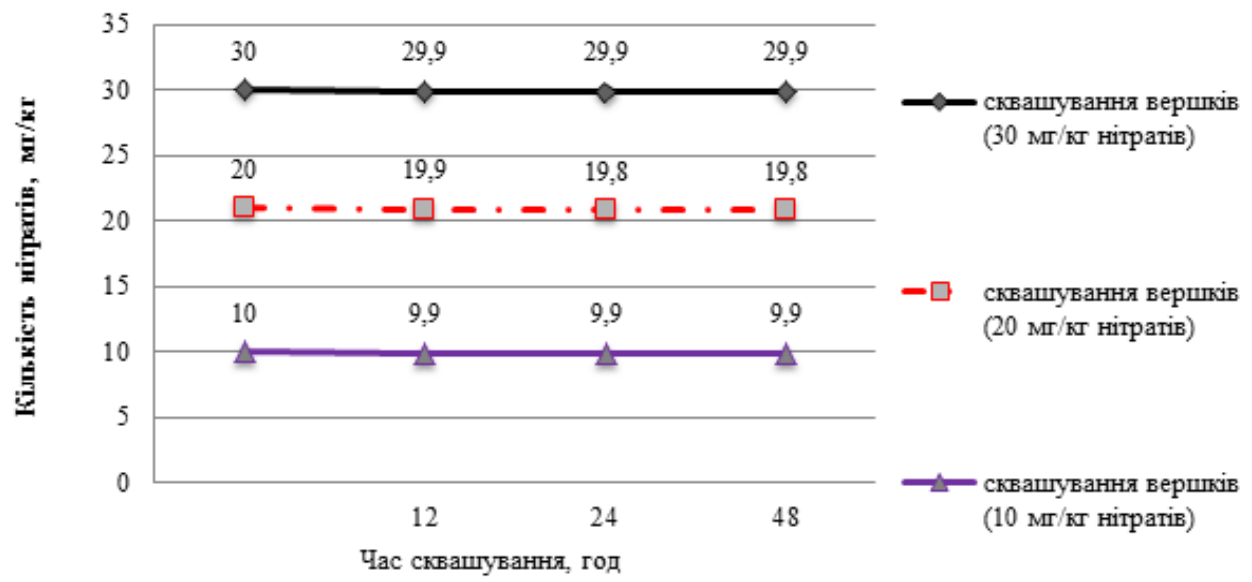

Рис. 3. Результати досліджень зміни кількості нітратів під час виготовлення кисломолочного продукту (сметани) з використанням закваски мезофільних бактерій (L. lactis, L. cremoris, S. diacetylactis)

Результати цих досліджень виявили, що під час процесу сквашування вершків протягом 24 год як такого зменшення вмісту нітратів не відбулось (до 1\%). Кількість нітратів під час подальшого сквашування (48 год) залишилася без змін.

Закваски термофільних (L. d. bulgaricus та S. thermophile) і мезофільних бактерій (L. lactis, L. diacetylactis, L. cremoris) не проявляють денітрифікуючої здатності і тому не можуть зменшити наднормативну кількість нітратів у сировині до допустимих норм.

Отже, проведені дослідження, результати яких наведенні на рис. $1-3$, вказують на те, що процес денітрифікації сирого молока з різним вмістом нітратів активно проходить в перші 24 год лише під час природного сквашування молока за рахунок власної мікрофлори, яка проявляє денітрифікуючу здатність. Ми вважаємо, що процес денітрифікації проходить за класичною схемою, яка включає три фази [12]:

$$
\begin{gathered}
3 \mathrm{HNO}_{3} \rightarrow 2 \mathrm{HNO}_{2}+\mathrm{O}_{2} ; \\
2 \mathrm{HNO}_{2} \rightarrow \text { проміжні сполуки }+\mathrm{O}_{2} ; \\
\text { проміжні сполуки } \rightarrow \mathrm{N}_{2}+\mathrm{H}_{2} \mathrm{O}+\mathrm{O}_{2} .
\end{gathered}
$$

Класичні закваски, які вносять згідно з технологічними інструкціями при виробництві йогурту та сметани не проявляють денітрифікуючу здатність. Імовірною причиною $є$ те, що в технології виготовлення йогурту і сметани молоко попередньо піддається термічній обробці і це призводить до загибелі денітрифікуючих бактерій сирого молока.

Перспектива подальших досліджень полягає в пошуку заквасочних культур, які б проявляли денітрифікуючу здатність і могли б застосовуватись у виробництві кисломолочних продуктів, зокрема йогурту і сметани. 
Висновки. Встановлено, що власна мікрофлора молока-сировини проявляє активну денітрифікуючу здатність в перші 24 год. Однак за кількості нітратів у молоці понад 20 мг/кг власна мікрофлора молока-сировини не здатна денітрифікувати їх до європейських вимог 5 мг/кг.

Досліджено, що закваски з вмістом молочнокислих культур Lactobacillus delbrueckii subsp. bulgaricus та Streptococcus salivarius subsp. thermophilus, які використовуються при виробництві йогурту і закваски з мікроорганізмами Lactococcus lactis subsp. lactis, Lactococcus lactis subsp. diacetylactis, Lactococcus lactis subsp. cremoris, що використовуються при виробництві сметани, не проявляють денітрифікуючу здатність.

\section{ЛІТЕРАТУРА}

1. Бондаренко Ю. Г. Медико-гігієнічна оцінка впливу нітратів води децентралізованих джерел водопостачання на стан здоров'я дітей раннього віку / Ю. Г. Бондаренко, В. В. Папач, Л. І. Білик // Довкілля та здоров’я. — 2011. — №4(59). - С. 23-26.

2. Смоляр В. І. Нітрати, нітрити та нітрозоаміни у харчових продуктах і раціонах / В. I. Смоляр, О. І. Циганенко, Г. І. Петрашенко // Проблеми харчування. — 2007. № 3. - С. 7-8.

3. Шелихов П. В. Исследование содержания нитратов в молоке дойных коров УНВАК ЛНАУ «Колос» / П. В. Шелихов, В. П. Левицкий // Безпека продуктів харчування та технологія переробки: збірник наукових праць ВНАУ. — 2013. — № 1(71). — С. 171-177.

4. Логачова Л. О. Вплив забруднення води нітратами на санітарну якість молока в умовах особистих господарств / Л. О. Логачова, Т. О. Тарасова, А. В. Шаболтас // Проблеми зооінженерії та ветеринарної медицини: зб. наук. праць. - Ветеринарні науки. — Харків, 2008. - Вип. 16(№41). — Том 1. - Частина 2. - С. 210-214.

5. Мусієнко М. Т. Вміст нітратів у молоці та метгемоглобіну в крові корів як показник поживної цінності зимових раціонів / М. Т. Мусієнко [та ін.] // Науковий вісник ЛНУВМБТ імені С. 3. Гжицького. - 2008. — Том 10, № 3(38). — Частина 1.— С. 162-164.

6. Писків С. І. Моніторинг вмісту нітратів у молоці / С. І. Писків, М. Д. Кухтин // Науковий вісник ЛНУВМБ імені С. 3. Гжицького. - Львів. - 2018. - Том 20, № 85.C. 41-45. doi: 10.15421/nvlvet8508.

7. Quijano L. Risk assessment and monitoring programme of nitrates through vegetables in the Region of Valencia (Spain) [Text] / L. Quijano, V. Yusà, G. Font, C.Allister, C.Torres, O. Pardo // Food and Chemical Toxicology. - 2017. — Vol. 100. — P. 42-49. doi: 10.1016/j.fct.2016.12.010.

8. Директива Ради 92/46 ЄЕС від 16 червня 1992 р. / Молоко та молочні продукти. Довідник у 3 томах. Том 3. Львів, Леонорм. 2000. С. 190-224.

9. Фізіологія сільськогосподарських тварин [Текст]: підручник для студ. вищих навч. закладів освіти III-IV рівнів акредитації зі спец. «Ветеринарна медицина» та «Технологія виробництва і переробки продукції тваринництва» / В. В. Науменко [та ін.]; За ред.: І. Д. Дерев'янка, А. С. Дячинського. - 2-ге вид., перероб. і доп. - К.: Центр навчальної літератури, 2009. - С. 161.

10. Миронова А. В. Обережно нітрати!!! / А. В. Миронова // Стандартизація. Сертифікація. Яість. - 2016. - № 3. - С. 60-61. Режим доступу: http://nbuv.gov.ua/ UJRN/ssia_2016_3_22.

11. Буряков Н. П. Влияние нитратов на мікрофлору рубца и продуктивность животных / Н. П. Буряков // Российский ветеринарный журнал. Сельскохозяйственные животные. Москва. - 2012. - №3. - С. 44. C. 139.

12. Капрельянц Л. В. Технічна мікробіологія / Л. В. Капрельянц та ін. — Одеса, 2006. — 


\title{
ВЛИЯНИЕ ЕСТЕСТВЕННОГО СКИСАНИЯ СЫРОГО МОЛОКА И ЗАВАСОЧНЫХ КУЛЬТУР ПРИ ИЗГОТОВЛЕНИЕ ЙОГУРТА И СМЕТАНЫ НА ПРОЦЕСС ДЕНИТРИФИКАЦИИ
}

\author{
С. И. Пыскив, Н. Д. Кухтын
}

Тернопольский национальный технический университет имени И. Пулюя

В статье на основе литературных источников освещена проблема сверхнормативного содержания нитратов в молоке-сырье, которое поступает на переработку. Проведено определение динамики содержания нитратов во время самоскисания молока сырого, а также после внесения классических заквасок в предварительно подготовленное молоко и сливки согласно технологии изготовления йогурта и сметаны соответственно. В технологическом процессе производства йогурта с использованием закваски с содержанием бактерий Lactobacillus delbrueckii subsp. bulgaricus u Streptococcus salivarius subsp. thermophilus и в технологии производства сметаны на закваске мезофильных молочнокислых бактерий Lactococcus lactis subsp. lactis, Lactococcus lactis subsp. diacetylactis, Lactococcus lactis subsp. cremoris определено, что процесc денитрификации не происходит. Подтверждена необходимость поиска закваски с содержанием молочнокислых микроорганизмов, которая оказывает денитрифицирующую способность при изготовлении кисломолочных продуктов, в частности йогурта и сметаны.

Ключевые слова: молоко, йогурт, сметана, денитрификация, закваска, сквашивание. 